\title{
Communication
}

\section{Oligodeoxyadenylate stimulates the protein kinase activity of anti-DNA sIgA from human milk ${ }^{\star \star}$}

\author{
Yuri Kit ${ }^{1, \bowtie}$, Elena Kuligina ${ }^{2}$, Dimitry Semenov ${ }^{2}$ and Vladimir Richter ${ }^{2}$ \\ ${ }^{1}$ Institute of Cell Biology, National Academy of Sciences of Ukraine, Lviv, Ukraine; \\ ${ }^{2}$ Novosibirsk Institute of Bioorganic Chemistry, Siberian Division of Russian Academy \\ of Sciences, Novosibirsk, Russia
}

Received: 17 September, 2001; revised: 20 December, 2001; accepted: 6 February, 2002

Key words: human milk, abzymes, anti-DNA antibodies, oligonucleotides, protein kinase activity

\begin{abstract}
Preparations of anti-DNA sIgA were obtained from human milk by sequential chromatography on protein A-sepharose, DEAE-fractogel and DNA-cellulose. The influence of oligonucleotides on protein kinase activity was investigated. It was discovered that incubation of anti-DNA SIgA with oligodeoxyriboadenylate $\mathrm{d}(\mathrm{A})_{12}$ stimulates the phosphorylation of polypeptides of sIgA in the presence of $\left[\gamma-{ }^{32} \mathrm{P}\right] \mathrm{ATP}$. The greatest was the incorporation of ${ }^{32} \mathrm{P}$ into the sIgA H-chains. We also demonstrated stimulation of the casein kinase activity of anti-DNA sIgA by $d(A)_{12}$. The stimulation of the protein kinase activity of anti-DNA sIgA by oligoriboadenylate $\mathrm{r}(\mathrm{A})_{12}$ was not detected.
\end{abstract}

It is known that human blood and secretory fluids contain antibodies (Ab) possessing affinity to mammalian DNA (anti-DNA Ab) [1, 2]. DNase and RNase activities of anti-DNA $\mathrm{Ab}$ have been discovered recently $[3,4]$. It was found earlier that secretory immunoglobulins A (sIgA) from human milk possessed protein kinase activity (sIgA-abzymes) [5-7]. We detected anti-DNA sIgA in the catalytically active sIgA preparations [8]. The presence of oligonucleotides tightly bound to sIgA in human milk was also

\footnotetext{
${ }^{\star}$ Preliminary report was presented at the 3rd Parnas Conference, September, 2000, Lviv, Ukraine.

The authors are deeply indebted to Dr. John C. Wallingford (Wyeth Nutritionals International, Philadelphia, U.S.A.) for the financial support of this work.

${ }^{\bowtie}$ Corresponding author: Kit Yuri, Institute of Cell Biology of National Academy of Sciences of Ukraine, Dragomanov 14/16, 79005, Lviv, Ukraine; tel.: (380) 322720 646; fax: (380) 322720 646; e-mail: kit@biochem.lviv.ua or yuyakit@yahoo.com
}

Abbreviations: Ab, antibodies; anti-DNA sIgA, secretory immunoglobulins A that bind with immobilized DNA. 
shown [8]. We suggest that anti-DNA sIgA possess a protein kinase activity which could be influenced by oligonucleotides.

\section{MATERIALS AND METHODS}

\section{Isolation of anti-DNA sIgA from human} milk. Secretory immunoglobulins were isolated from human milk of first day lactation by chromatography on protein A-Sepharose (Sigma, U.S.A.) according to [5]. IgG and sIgA were separated on a Fractogel TSK DEAE 650 (M) (Merck, Germany) column [7]. Anti-DNA sIgA preparations were obtained by chromatography on a column containing glutaraldehyde-modified calf thymus DNA immobilized on cellulose ( $1000 \mathrm{~A}_{260}$ units to $1 \mathrm{~g}$ cellulose) [8]. Proteins were eluted with $50 \mathrm{mM}$ $\mathrm{NaOH}$ and were dialyzed for $24 \mathrm{~h}$ against 20 $\mathrm{mM}$ Tris/ $\mathrm{HCl}, \mathrm{pH}$ 7.5. Proteins of the isolated fractions were analyzed by electrophoresis in $4-16 \%$ PAGE in the presence of $0.1 \%$ SDS [9]. Polypeptide spectrum analysis of sIgA preparations was performed by SDS-electrophoresis in $12 \%$ PAGE after addition of 2-mercaptoethanol to antibody samples.

Assay of protein kinase activity of anti-DNA sIgA preparations. Casein was isolated from human breast milk by precipitation at $\mathrm{pH} 4.6$ [5]. Protein kinase activity of anti-DNA sIgA preparations was analyzed in the presence or absence of casein. Reaction medium $(20 \mu \mathrm{l})$ contained $20 \mathrm{mM}$ Tris $/ \mathrm{HCl}$, $\mathrm{pH} 7.5,50 \mathrm{mM} \mathrm{NaCl}, 3 \mathrm{mM} \mathrm{MgCl}, 0.2 \mathrm{mg} / \mathrm{ml}$ sIgA, $50 \mu \mathrm{Ci}\left[\gamma_{-}{ }^{32} \mathrm{P}\right] \mathrm{ATP}, 1 \mu \mathrm{M}$ ATP, $1 \mathrm{mg} / \mathrm{ml}$ casein. Anti-DNA sIgA samples were preincubated with $0,0.5,1$ or $3 \mu \mathrm{M} 12$-mer riboadenylate $\mathrm{r}(\mathrm{A})_{12}$ or 12 -mer deoxyriboadenylate $\mathrm{d}(\mathrm{A})_{12}$ at $23^{\circ} \mathrm{C}$ for $15 \mathrm{~min}$. Reaction was performed at $37^{\circ} \mathrm{C}$ for $30 \mathrm{~min}$ and was stopped by addition of equal volume of $20 \%$ trichloroacetic acid. Protein pellet was washed with acetone, dissolved in buffer containing $50 \mathrm{mM}$ Tris/ $\mathrm{HCl}, \mathrm{pH}$ 6.8, 2\% SDS, $2 \%$ 2-mercaptoethanol, 10\% glycerol. Proteins were electrophoresed in 10\% PAGE in the presence of $0.1 \%$ SDS. The gel was dried and autoradiographed for $18 \mathrm{~h}$ on X-ray film (Fuji Photo Film, Japan).

\section{RESULTS AND DISCUSSION}

Anti-DNA sIgA preparations were obtained from human milk by sequential chromatography on protein A-sepharose, DEAE-sorbent and DNA-cellulose [8]. As far as we know
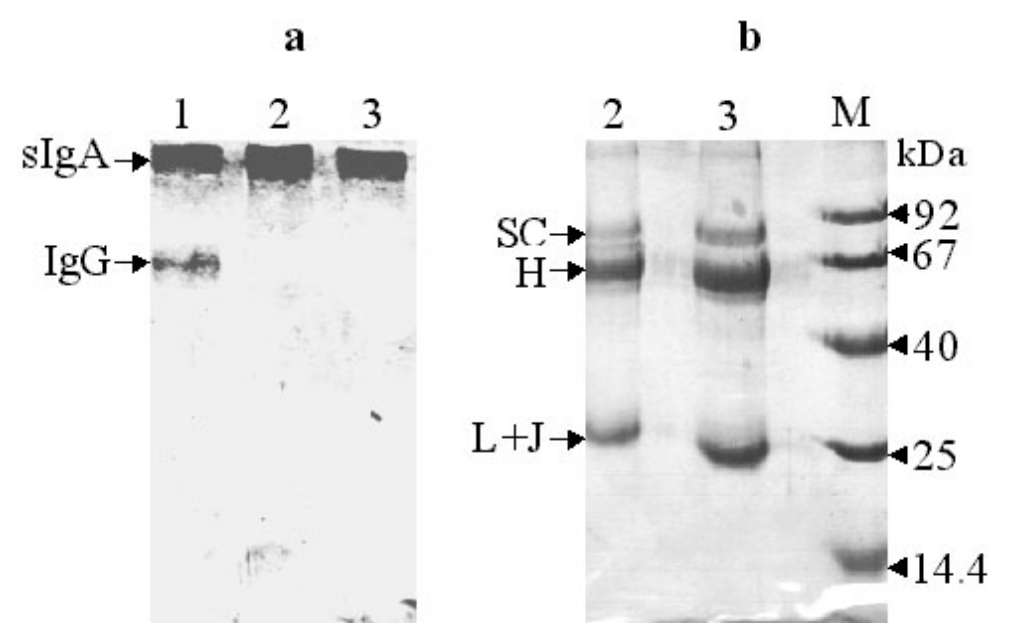

Figure 1. Electrophoretic analysis of sIgA preparations from human milk obtained by sequential chromatography on protein A-sepharose (lane 1), DEAE-sorbent (lane 2), DNA-cellulose (lane 3).

a) SDS-electrophoresis in 4-20\% PAGE in nonreducing conditions. b) SDS-electrophoresis in 12\% PAGE in reducing conditions. M, markers of molecular mass. The position of polypeptides of sIgA: SC, secretory component, $\mathbf{H}$, heavy chain, L+J, light and joined chains. Gels were stained with Coomassie BBR-250. 
sIgA-abzymes remain stable at alkaline conditions [8], so we used $50 \mathrm{mM} \mathrm{NaOH}$ as eluent in order to complete the elution of antibodies from DNA-cellulose. The purity of typical sIgA preparations is shown in Fig. 1. Electrophoretic analysis of the antibody fraction obtained by chromatography on DEAE-sorbent and DNA-cellulose shows a single band $(<150$ $\mathrm{kDa}$ ) in nonreducing conditions (Fig. 1a) and three bands $(72,62,25 \mathrm{kDa})$ in reducing conditions (Fig. 1b). Earlier we found that these polypeptides correspond to the secretory component of the H-chain and the $\mathrm{L} / \mathrm{J}$-chain of sIgA [5, 7]. Based on these data, we conclude that the antibody fraction possessing affinity to mammalian DNA is an electrophoretically pure anti-DNA sIgA preparation. We analyzed autophosphorylation of the anti-DNA sIgA in the presence of $\left[\gamma^{32} \mathrm{P}\right] \mathrm{ATP}$. Some incorporation of ${ }^{32} \mathrm{P}$ was detected into the secretory component and the H-chain of sIgA (Fig. 2). Incubation of anti-DNA sIgA with $\mathrm{d}(\mathrm{A})_{12}$ increased the phosphorylation of the sIgA polypeptides. The greatest incorporation of ${ }^{32} \mathrm{P}$ was observed into the H-chain of sIgA. The presence of $r(A)_{12}$ in the reaction medium did not influence sIgA phosphorylation. We have shown that sIgA-abzymes could phosphorylate residues of human milk casein [5-7]. We studied the influence of oligonucleotides on the casein kinase activity of anti-DNA sIgA preparations. Ribooligoadenylate $\left(\mathrm{r}(\mathrm{A})_{12}\right)$ did not influence the phosphorylation of casein in the presence of anti-DNA sIgA (Fig. 3). On the other hand, $\mathrm{d}(\mathrm{A})_{12}$ was able to stimulate the phospho-

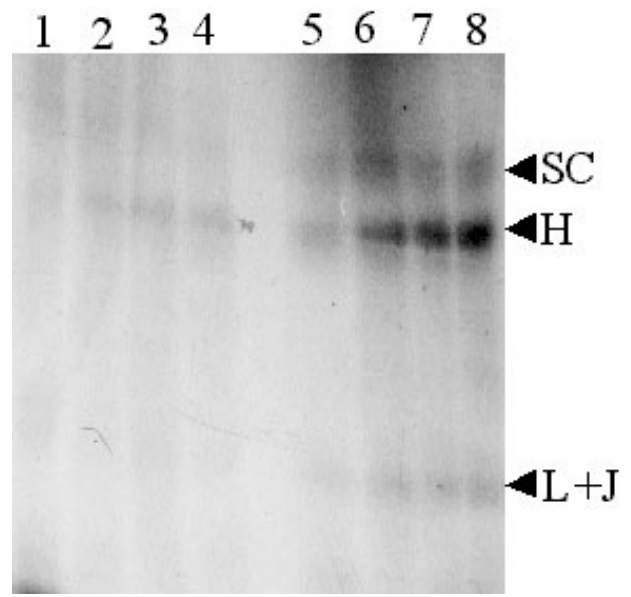

Figure 2. Electrophoretic analysis of anti-DNA sIgA phosphorylation in the presence of oligonucleotides and $\left[\gamma-{ }^{32}\right.$ P $]$ ATP.

1-4) Preparation was incubated with $0,0.5,1,3 \mu \mathrm{M}$ $\mathrm{r}(\mathrm{A})_{12} .5-8$ ) Preparation was incubated with $0,0.5,1,3$ $\mu \mathrm{M} \mathrm{d}(\mathrm{A})_{12}$.

The position of polypeptides of sIgA: SC, secretory component, $\mathbf{H}$, heavy chain, $\mathbf{L}+\mathbf{J}$, light and joined chains. An autoradiograph of the gel is shown.

rylation of casein (Fig. 3) as well as the auto-phosphorylation of anti-DNA sIgA (Fig. 2). Consequently, oligodeoxynucleotides are able to stimulate the protein kinase activity of anti-DNA sIgA. Based on the obtained data, we suggest that anti-DNA sIgA preparations from human milk possess an oligodeoxynucleotide-dependent (presumably DNA-dependent) protein kinase activity. Considering the purity of the anti-DNA sIgA preparations, we conclude that the protein kinase activity is an intrinsic property of anti-DNA sIgA. It has been shown that sIgA-abzymes from human milk are able to bind casein and ATP

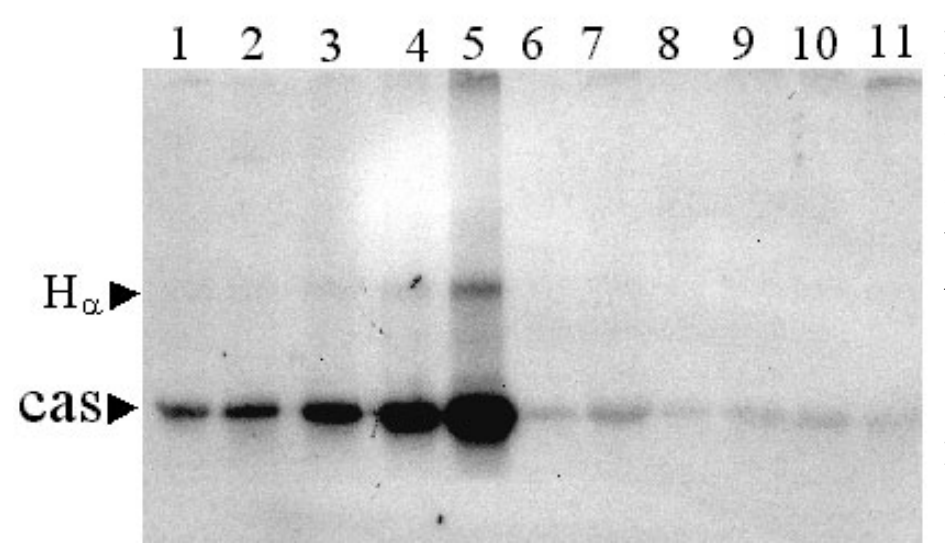

Figure 3. Electrophoretic analysis of casein kinase activity of anti-DNA sIgA in the presence of oligonucleotides and $\left[\gamma-{ }^{32} \mathrm{P}\right] \mathrm{ATP}$.

Preparation $(0.2 \mathrm{mg} / \mathrm{ml} \mathrm{sIgA})$ was incubated with $1 \mathrm{mg} / \mathrm{ml}$ casein, $50 \mu \mathrm{Ci}\left[\gamma-{ }^{32} \mathrm{P}\right] \mathrm{ATP}, 1 \mu \mathrm{M}$ ATP for $30 \mathrm{~min}$ at $37^{\circ} \mathrm{C} .1-5$ ) In the presence of $\left.0.1,0.5,1,2.5,3 \mu \mathrm{M} \mathrm{d}(\mathrm{A})_{12} .7-11\right)$ In the presence of $0.1,0.5,1,2.5,3 \mu \mathrm{M} \mathrm{r}(\mathrm{A})_{12} .6$ ) Without oligonucleotides. The position of polypeptides: $\mathbf{H}_{\alpha}$, havy chain of sIgA, cas, casein. 
cross-reactively [7, 10, 11]. Maybe the sIgA-abzymes are related to the class of polyreactive antibodies of human milk [12, 13] that can interact with mammalian DNA [13]. It is known that sIgA get into secretory fluids by transcytosis through the epithelial tissue [14] and sIgA antibodies can inhibit reproduction of viruses infecting epithelial cells [15]. So such anti-DNA sIgA with protein kinase activity themselves can be potentially antipathogenic agents for epithelial cells.

\section{R E F E R E N C E S}

1. Dawson, K.H. \& Bell, D.A. (1991) Antisense Res. Dev.. 1, 351-360.

2. Bouvet, J.P. \& Dighiero, G. (1998) Infect. Immun. 66, 1-4.

3. Shuster, A.M., Gololobov, G.V., Kvashuk, O.A., Bogomolova, A.E., Smirnov, I.V. \& Gabibov, A.G. (1992) Science, 256, 665-667.

4. Buneva, V.N., Kanyshkova, T.G., Vlassov, A.V., Semenov, D.V., Khlimankov, D.Yu., Breusova, L.R. \& Nevinsky, G.A. (1998) Appl. Biochem. Biotechnol. 75, 63-76.

5. Kit, Y.Y., Kim, A.A. \& Sidorov, V.N. (1991) Biomed. Sci. 2, 201-205.

6. Kit, Y.Y., Semenov, D.V. \& Nevinsky, G.A. (1996) Biochem. Mol. Biol. Int. 39, 521-527.
7. Nevinsky, G.A., Kit, Y.Y., Semenov, D.V., Khlimankov, Yu.D. \& Buneva, V.N. (1998) Appl. Biochem. Biotechnol. 75, 77-91.

8. Kit, Y.Y., Semenov, D.V., Kanyshkova, T.G., Kuligina, E.V., Romannikova, I.V., Morozova, O.V. \& Richter, V.A. (1999) Biochemistry (Mosc.) 64, 52-59.

9. Laemmli, U.K. (1970) Nature 227, 680-685.

10. Kit, Y.Y., Shipitsin, M.V., Semenov, D.V., Richter, V.A. \& Nevinsky, G.A. (1998) Biochemistry (Mosc.) 63, 133-139.

11. Kit, Y.Y., Semenov, D.V. \& Nevinsky, G.A. (1995) Mol. Biol. (Mosc.). 29, 893-905.

12. Quan, C.P., Berneman, A., Pires, R., Avrameas, S. \& Bouvet, J.P. (1997) Infect. Immun. 65, 3997-4004.

13. Vassilev, T.L. \&Veleva, K.V. (1996) Scand. J. Immunol. 44, 535-539.

14. Kaetzel, C.S., Robinson, J.K., Chantalacharuvu, K.R., Vaerman, J.P. \& Lamm, M.E. (1991) Proc. Natl. Acad. Sci. U.S.A. 88, 8796-8800.

15. Mazanec, M.B., Kaetzel, C.S., Lamm, M.E., Fletcher, D. \& Nedrud, J.G. (1992) Proc. Natl. Acad. Sci. U.S.A. 89, 6901-6905. 